\title{
FINANCING OF FINANCIAL STATEMENTS USING COMPUTER APPLICATION (STUDY ON COOPERATION IN KLATEN)
}

\author{
Tjahjanto $^{1 *}$, Indah Rahayu Lestari ${ }^{1}$, Rinny Meidiyustiani ${ }^{1}$ \\ ${ }^{1}$ Departement of Accounting, Faculty of Economic and Business, Budi Luhur University \\ *cahyanto2000@gmail.com
}

\begin{abstract}
The purpose of this Community Service activity is to improve the basic knowledge of accounting, as well as the preparation of simple financial statements by utilizing the accounting information technology. Based on survey results to 11 cooperatives in Klaten it can be identified problems as follows: 1) Not well-organized bookkeeping. 2) Recording is still done manually and not yet supported by computer-based information system technology. Based on the problems faced by the cooperative, the solutions offered to cooperatives are debriefing of accounting knowledge as the basis for preparation of financial statements of cooperatives, as well as the creation of cooperative accounting programs, demonstrations, and training. Currently the first phase of the activity has been going well and smoothly. Where in this stage the cooperative began to run the preparation of financial statements by using the accounting information system technology, using TJFinanceprogram. Assistance in the utilization of cooperative accounting system that has been made, among others in the form of mentoring preparation, as well as assistance in the use of cooperative accounting system. So that the existing system can be utilized more optimally and can be developed in accordance with the needs of the cooperative management as a partner of dedication and other cooperative management members in Klaten. In addition there is an increased role of stakeholder better associated with the creation and development of cooperative applications so that in the future will be the application development process when running in accordance with what is expected by the cooperative.
\end{abstract}

Keywords: Accounting Information System, Cooperative, Financial Report, Technology

\section{INTRODUCTION}

Every business is expected to have financial statements to analyze financial performance so that it can provide information about the financial position, performance and cash flow of the company that is useful for users of financial statements in order to make economic decisions and show management accountability for the use of resources entrusted to them. No exception with cooperatives. Cooperative financial statements are also made to provide information presented to be easier to understand, have relevance, reliability with high comparability. Cooperatives as social economic institutions that are social in nature must be further developed and strengthened in order to foster economic democracy as one of the foundations for the creation of a socially just society. Cooperative financial statements are also made to provide information presented to be easier to understand, have relevance, reliability with high comparability.

The benefits of cooperatives are expected to be felt directly by the members involved in them. The activities carried out by cooperatives are not solely solely for profit seeking, but are expected to educate and create enthusiasm for entrepreneurship in the hearts of members. However, cooperatives still have to make financial statements. With the making of this financial report will provide information concerning financial position, performance and changes in financial position. This financial report also shows what has been done by the management of the cooperative or the accountability of the cooperative management of the resources entrusted by other members. The cooperative's financial report contains at least an annual calculation consisting of a statement of financial position at the end of the new financial year and a calculation of the results of the business of the year concerned and an explanation of the document, as well as the state of the cooperative business and the results of the business that can be achieved. Klaten is a city that is part of Central Java. Formed based on PP 41/1986 
and PP 33/2003. The forerunner of this city was from KlatenSubdistrict which was later expanded as an administrative city by cooperating with several surrounding districts. Broadly speaking, the city of Klaten is not an industrial or trade city. Until now industrial activities have only been focused on JalanDiponegoro. There are also hundreds of cooperatives in the city of Klaten, according to the Head of Cooperatives and Small Micro Enterprises, the Trade and Cooperative Office (Disdagkop) and the Klaten UMKM, Yunanta (published in Solopos August 15, 2017), said in Klaten there are around 953 cooperatives. Of that amount, 893 cooperatives are still active. But there are 60 cooperatives still in the dissolution stage by the government. On average, the proposed cooperative was dissolved because there were no activities rolled out, there were no inactive management or management and no members or less than 20 members. The average cooperative was dissolved before managing savings and loans. The need for ongoing coaching is an effort to maintain the existence of cooperatives. Healthy or not a cooperative can be measured through criteria including financial management, activities including facilities and infrastructure.

The PKM activity object is a sharia cooperative located in the city of Klaten, Central Java. Cooperatives include active cooperatives, where cooperative activities are still a cooperative savings and loan. But for the implementation of financial statements, cooperatives still have not recorded and prepared financial statements.Sharia Savings and Loans Operations Activities which in this case are referred to as Sharia Financial Services Businesses are activities carried out to raise funds from members and channel them through the mechanism of the Sharia Financial Services business from and intended for distribution to cooperative members, prospective members of cooperatives or other cooperative members.

\section{Problem}

Based on these conditions, it is necessary to manage professional cooperative management. The problems that are often faced are: 1) The cooperative bookkeeping has not been well organized. 2) Recording that is still done manually and not supported by computer-based information system technology. The need for ongoing coaching is an effort to maintain the existence of cooperatives. Healthy or not a cooperative can be measured through criteria including financial management, activities including facilities and infrastructure.

Information technology is a computer technology-based technology. The rapid development of information technology lately, allows making data processing information systems that provide information results. This of course makes it easy for business people, even cooperative management to process financial data. So that it helps to make business decisions. The program for cooperatives that still has to be carried out is Remaining Business Outcomes, can be excluded for the part of the cooperative management, cooperative education programs, social and work area development. By carrying out the recording and compilation of financial statements on cooperatives, it can be known the state of the business and the results of the business achieved. It is hoped that cooperatives can develop their business fields, not only savings and loan cooperatives. But it can develop into cooperative cooperative production and consumption cooperatives. The benefits that can be felt by members will be more and more. 


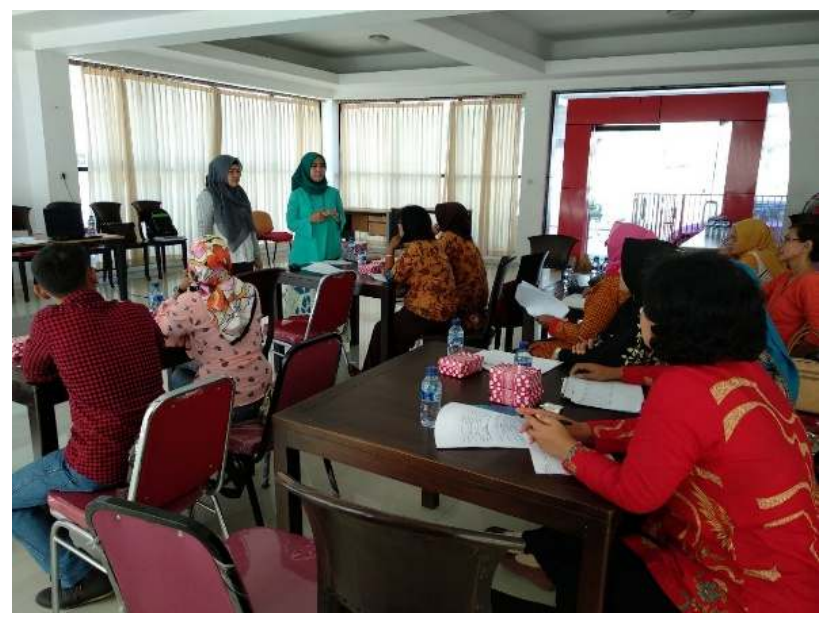

Figure 1. Basic Accounting Training

\section{Extensive Target}

This service activity works with 11 Sharia Cooperatives in Klaten Regency, Central Java. Cooperatives include active cooperatives, where cooperative activities are still a sharia savings and credit cooperative. But for the implementation of financial statements, cooperatives still have not recorded and prepared financial statements. Sharia Savings and Loans Operations Activities which in this case are referred to as Sharia Financial Services Businesses are activities carried out to raise funds from members and channel them through the mechanism of the Sharia Financial Services business from and intended for distribution to cooperative members, prospective members of cooperatives or other cooperative members.

Community Service (PKM) is carried out to find out the constraints faced by cooperatives in preparing simple financial statements and to design a simple accounting system that can help and facilitate the cooperative management in making simple financial statements. With the financial statements, it is expected that the cooperative management can evaluate its business and can use the information in the financial statements as a basis for decision making.

\section{METHOD}

The methods carried out in this service include:

a. Basic Accounting Knowledge

b. Making and Utilizing Accounting Information Systems

Methods carried out in this service include training in basic accounting and the making of simple cooperative financial statements, the creation of cooperative accounting information systems programs, demonstrations and program training, then reviewing cooperatives to find out what technical constraints faced by cooperatives. For the steps taken in this service are: 1) debriefing and training in basic knowledge of cooperative accounting and financial reporting, 2) Making and utilizing cooperative accounting information system programs, 3) Reviewing cooperatives to find out more about the obstacles faced in carrying out the recording and financial reporting.

Starting from collecting transaction documents, making journals, ledgers, adjusting journals, to simple financial statements for cooperatives. The second day of training on 11 April 2018 participants were trained to use a computerized accounting cooperative system that uses the TJFinance system. Starting with entering member data, then proceed to try using a journal. The program on the second and third days also continued with a visit to the assisted cooperatives, to find out what obstacles faced in carrying out computer-based accounting records. 


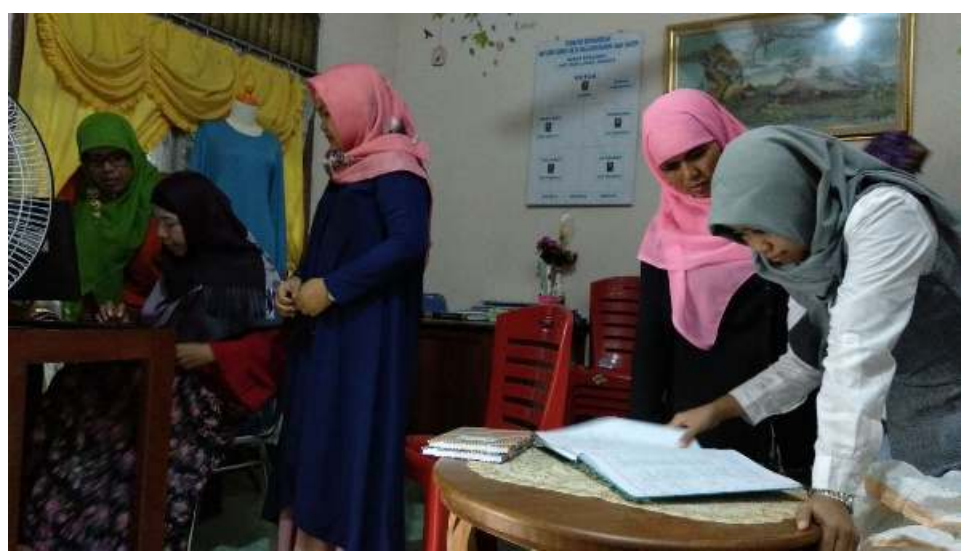

Figure 2. Checking Documentation

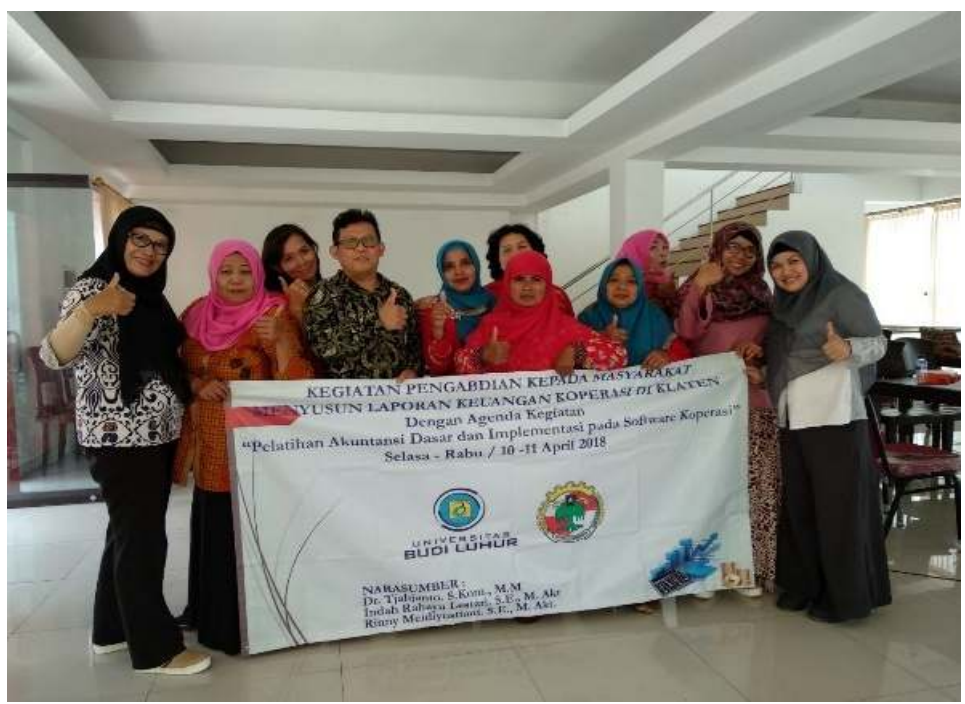

Figure 3. Training Participants

\section{RESULT AND DISCUSSION}

All dedication activities have been carried out with good results and enthusiasm from the cooperative management. Where the steps taken in this service are: 1) debriefing and training in basic knowledge of cooperative accounting and financial reporting, and 2) Making and utilizing the cooperative accounting information system program. The cooperative management hopes that further training will be held on the accounting basis and practice for accounting compilation.

At the utilization stage of the cooperative accounting information system program, the cooperative created a computerized accounting program called TJFinance. It is expected that by facilitating the program can be more maximizing in preparing financial statements. With the implementation of an additional agenda in the form of visits to fostered cooperatives, it is expected to know more what is needed by the cooperative management in carrying out cooperative financial reporting. 


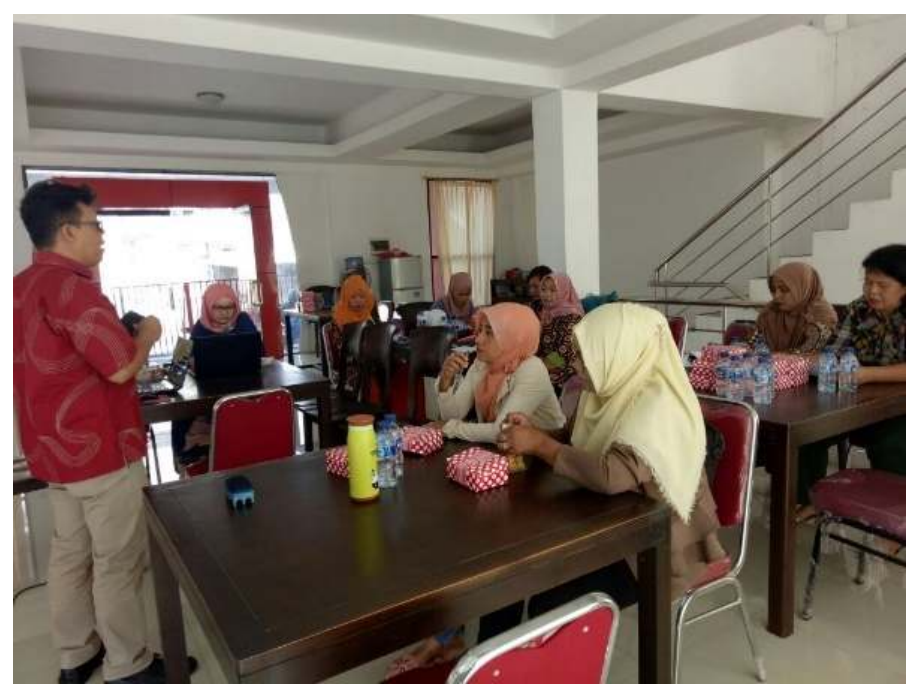

Figure 4. Accounting Information System Training

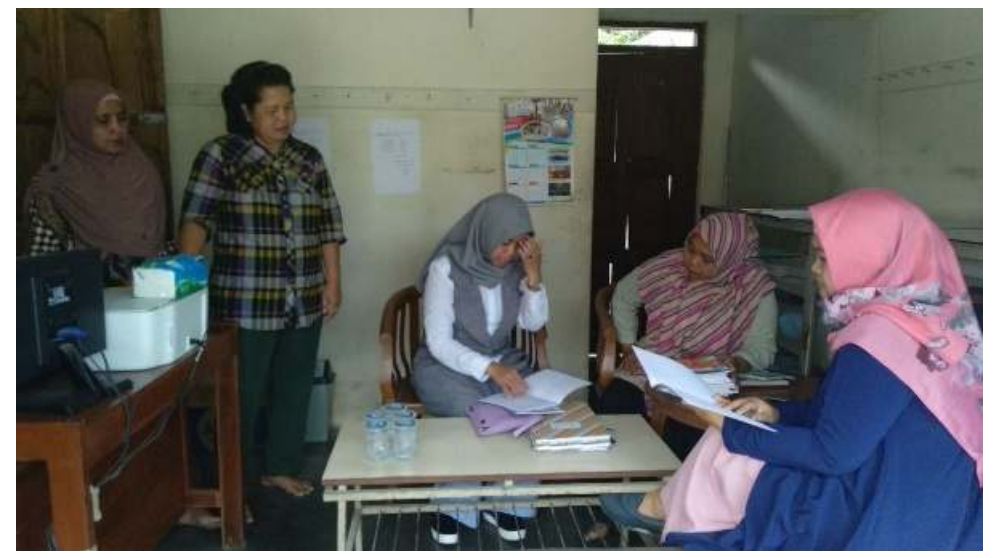

Figure 5. Checking Manual Report

\section{CONCLUSION}

\section{Conclusion}

Dedication activities have been completed, so that it can be concluded from 2 (two) stages of service that have been carried out. Cooperative partners actively participate in each activity, and work well together in achieving the objectives of the activity. The management of each cooperative is present in every service activity. With this activity alsoincreases the motivation of the management to be able to utilize the cooperative accounting information system program that has been created, so that it can prepare and compile the financial statements of the cooperative, which previously only recorded money in and out. Not yet recorded in the form of financial statements.

\section{Suggestion}

It should be uniformed for manual recording documents, which are used as transaction documents. This is seen when a direct visit is made to the cooperative. Where each has a different transaction document in each cooperative. The uniformity of this document is carried out, considering that all cooperatives are cooperatives which are also established by the Budi LuhurCakti Foundation as Community Service to improve the welfare of the Klaten community. The existence of follow-up activities in the form of mentoring, thus increasing the ability and skills of cooperative administrators in preparing financial statements using the accounting information system created. 


\section{RERFERENCES}

Stoner, James A.F. (1982). Management, 2nd ed., Prentice-Hall.

TaufikSidik/Prakoso/JIBI/. 2017. SoloposKlaten

TribunBisnis, Rabu 27 September 2017

Weygandt, Kimmel, Kieso. (2013) Financial Accounting, IFRS Edition: 2e. Cita.

YonMujiyono, 5 Agustus 2016, rri.co.id

http://www.depkop.go.id

http://hariannetral.com/2015/01/pengertian-koperasi-tujuan-fungsi-dan-jenis-koperasi.html\# 